\title{
"Yer" in Anlamının Araştırıcısı Olarak Sokak İsimleri: İzmit/Akçakoca Tarihi Bölge Örneği
}

*

\author{
Zeynep Gamze Mert ${ }^{1}$ \\ ORCID: 0000-0003-1896-4652
}

\author{
Filiz Ertürk ${ }^{2}$ \\ ORCID: 0000-0003-4105-3929
}

\section{Öz}

Yer isimleri kentsel ortamda yerin ekonomik, politik güçleri ile sosyal ortamın ve çevresel özelliklerini yansıtmasından dolayı yerin anlamın keşfetmek için önemli bir araştırma alanıdır. İsimlerinin gündelik hayatın içinde yer alması nedeniyle, sokăğ anlamak, bölgeyi, kenti, ülkeyi anlamanın ilk adımını oluşturmaktadır. Literatürde, sokak isimleri aracılı̆̆ıyla yerin anlamını araştıran herhangi bir çalışmaya rastlanmamıştır. Bu çalışma; bir yol haritası ile sokak isimlerini yerin anlamının araştırıcısı olarak tanımlamayı amaçlamıştır. Yol haritası üç aşamadan oluşmaktadır; göstergelerinin elde edilmesi, sokak isimleri bilgi kartlarının oluşturulması, yerin anlamın tanımlama. Anlam analiz yaklaşımlarından (göstergebilim) semiyolojik ve (yorumbilim) hermeneutik yaklaşımlar, tüm aşamalarda izlenmiştir. İlk olarak, 5N1K yöntemi ile sokak isimlerinin göstergeleri elde edilmiş; ikinci olarak, gösterge ve yorumlarn içeren sokak isimleri bilgi kartları tasarlanmış ve oluşturulmuş ve son olarak, bilgi kartların bir araya getirerek üretilen göstergeler aracılığılyla yerin anlamı tanımlanmıştır. Bu makale, İ-mit/Akçakoca tarihi bölgede çalışma yaparak, sokak isimlerinin geçmişten günümüze o yerin anlamının işareti ve araştırıcısı olduğunu, bir yol haritası aracılı̆̆ıla yerin anlamı hakkında önemli bilgi ürettiğini göstermiştir.

Anahtar Kelimeler: İmit/Akçakoca tarihi bölge, sokak, sokak isimleri, yer, yerin anlamı.

\footnotetext{
${ }^{1}$ Doç, Dr., Gebze Teknik Üniversitesi, E-mail: gamzemert@gtu.edu.tr

${ }^{2}$ Dr. Araştırmacı, İzmit Belediyesi, E-mail:erturkk.filiz@gmail.com

idealkent (c) Kent Araştırmaları Dergisi (Journal of Urban Studies) 


\title{
Street Names behind investigating the meaning of "Place": İzmit/Akçakoca Historical Core Case
}

\author{
Zeynep Gamze Mert ${ }^{3}$ \\ ORCID: 0000-0003-1896-4652
}

\author{
Filiz Ertürk ${ }^{4}$ \\ ORCID: 0000-0003-4105-3929
}

\begin{abstract}
Place names are an important research area to discover the meaning of place as it reflects the place's economic, political powers, social structure and environmental characteristics in urban environment. Understanding the streets' meaning is the first step in understanding the city's, region's and country's meaning; because their names are included in everyday life. In literature, there has not been any study which investigates the place meaning through street names. This study aims to define street names as investigators of the place meaning through a road map. The road map consists of three stages; acquiring indicators, documenting "street name information cards" and identifying the meaning of place. The meaning analysis approaches, semiologic and hermeneutic are followed in all stages. First, the indicators of street names are acquired through the 5W1H method; second, "street names information cards" are designed and documented; and the last, the meaning of place are identified through the new indicators produced by combining the information cards. Studying Izmit / Akçakoca Historical core, this paper shows that street names are the sign of the meaning of place from the past to the present, and they produce important information about the meaning of a place through a road map.
\end{abstract}

Keywords: İzit/Akçakoca historical core, meaning of place, place, street, street names.

\footnotetext{
${ }^{3}$ Assoc. Prof., Gebze Technical University, E-mail: gamzemert@gtu.edu.tr

4 PhD. Researcher, İzmit Municipality, E-mail:erturkk.filiz@gmail.com

idealkent (c) Kent Araştırmaları Dergisi (Journal of Urban Studies) 


\section{Giriş}

20.yy in son çeyreğinden itibaren kentsel ortamlar, küreselleşmenin yarattığ1 aynılaşma, tek tipleşme gibi unsurlarla yer olmayanların çoğaldığı bir yapı sergilemektedir. Bu nedenle yer olgusu, özellikle mekân ve toplum çalışmalarında giderek önem kazanmaktadır. Yer kavramı birçok araştırmacı tarafından farklı açılardan ele alınmıştır. Bazıları toplumsal ve kültürel bir yapı olarak, bazıları konum olarak, bazıları kimlikleyici özellikleri açısından, bazıları da deneyim alanı olarak kavrama yaklaşmışlardır. Antropoloji disiplini açısindan konuya yaklaşan Augé "yer" $i$, eşzamanlı olarak orada yaşayanlar için bir anlam ve orayı gözlemleyenler için de bir anlaşılırlık olarak ifade eder (Augé, 1992/2016, s.12). Ayrıca yerin kimlikleyici, ilişkisel ve tarihsel olması özelliğini vurgular. Norberg-Schulz (1980), yer kavramını, yaşanan alan olarak ele almıştır. Yaşantının geçtiği yer, mekân ve karakter kavramlarının bütünü ve bunlar arasındaki ilişkidir. Bununla birlikte yer, anlam, kimlik ve tarihselliği barındıran, toplumsal özellikleri yansıtan, günlük deneyimler alanı, yaşamı görünür kılan, hareketlerin ve olayların geçtiği, işlevsel, kültürel özellikler taşıyan, geleneksel unsurlara sahip, ilişkilere olanak sağlayan ortamdır. Günlük yaşamlarımızda yerlerin, yalnızca konumları veya görünümleriyle tanımlanabilecek alanlar olmadığının altını çizen Relph (1976)'e göre yerler, aksine, bir düzen, manzara, ritüel, rutin, diğer insanlar, kişisel deneyimler ve diğer yerler bağlamında algılanırlar. Bölgelerin doğal yapısı, ekonomik ve kültürel ürünleri ile üzerinde yaşayan canlılardan etkilenen yer isimleri ise, yerleşimlerin tarihi bakımdan önemli belgeleri arasındadır. Yer isimleri Fransizca "toponymie"den gelen, Türk Dil Kurumu tarafından "Yer adları bilimi" olarak tanımlanan Toponimi dalı içinde incelenmektedir. "Toponimi" sözcügü Yunancadan "topos" ve "onoma" kelimelerinden türetilmiştir. "Topos" yer ve "onoma" isim anlamına gelmektedir (Aliağaoğlu ve Uzun, 2011, s. 123133). Toponimi içinde özellikle sokak, meydan, park alanlarının isimleri günlük dil ile ilişkili olmasından dolayı 'yer' in oluşumunda ve algılanmasında önemli bir role sahiptir. İsimler sahip oldukları yerlerin farklı dönemlerine tanıklık ettikleri için, ekonomik güçler, sosyal yaşamlar ve çevresel özellikler hakkında fikir verirler. Assmann (1997/2015)' a göre, belleğin oluşumunda çevre ne kadar önemliyse, o çevreyi tanımlayan yer isimleri de son derece önem taşımaktadır. Çünkü yer isimleri belleğin kodlarını ve kodların aktarımını sağlayan en önemli araçlardandır. Kentsel çevrenin isimlendirilmesi, nesilden nesile anlamlar taşıyarak yerin anlamının keşfedilmesine yardımcı ol- 
maktadır. Ayrıca, isim değişiklikleri küresel dünyanın etkileri altındaki politik eğilimleri ve hedefleri göstermektedir. Böylece, günlük dilin bir parçası olarak, isimler kimlik hatırlama, unutma ve aidiyet unsurları gibi etkili bir şekilde işlev görürler. Særheim (2008)'in ifade ettiği gibi: "Yer isimleri geçmişin bağlantıları ve geleceğin imzasıdır". Görülüyor ki; yer isimleri, doğal, sosyal, kültürel değerleri ve bölgesel kimliği yansıttığı kadar korumayı ve gelişmeyi de teşvik etmektedir.

"Yer"ler kent ölçeğinde; sokak, komşuluk birimi, mahalle, semt, ilçe gibi çeşitli düzeylerden oluşur. İnsan önce yaşadığı kente bir isim verir. Bu isimlendirme kentten mahallelere ve oradan da sokaklara yayılır. Her isimlendirme, o yerin izlerini, anlam dünyasından bir parçasını taşır. Böylece soyut anlam, somut bir gerçekliğe dönüşür.

Yer ile ilgili yapılacak araştırma ve çalışmaların birinci koşulu o yeri anlamaktır. Kent dokusunun oldukça büyük bir bölümünü oluşturan en küçük kamusal kentsel öge olan sokakların taşıdığı isimler; o sokağı, o mahalleyi, o kenti, dolayısıyla o yeri anlamamızın ilk adımını oluşturur. Çünkü sokak Norberg-Schulz (1971)'a göre; geçmiş ve günümüz ile bölgenin ve kentin karakterini bir bütün olarak ziyaretçiye yoğun bir şekilde sunan "küçük bir evren" dir. Rapoport (1987); yerleşim yerlerinde bulunan binaların kenarındaki dar ya da geniş düz boşluklar olan sokakların aktivite ve insan sayesinde canlı bir öğe olduğunu anlatır. Sokaklar önemli bir kentsel bileşendir ve onu önemli kentsel bileşen yapan, toplumsallaşmaya katkısı ve yayanın kentle ilgilenmesini sağlamasıdır. Krier (1991) de sokağı benzer bir şekilde, kentsel dokunun hareket etmeyen öğeleri olan binalar arasında, insanların günlük aktivitelerini geçirdiği hareketli mekânlar olarak tanımlamaktadır. Sokaklar, kent karakteri ve kent kimliğinin anlaşılmasında önemli yerlerdir. Jacobs (1961/2017)'a göre “Bir kentin sokakları ilginç görünürse, kent de ilginç görünür, sevimsiz görünürse kent de sevimsiz görünür". İnsanların birlikte yaşamaya başladığı sokaklar, paylaşım, ulaşım ve hareketliliğin ortaya çıktığı kamusal mekânlardır. İnsanların üzerinde hareket ettiği kentsel izlerdir.

Bu yaklaşımlar sokağın o yer ile ilgili birçok şey ifade ettiğini vurgulamaktadır. Gündelik hayatın ve gündelik dilin içinde olan sokak isimleri de, yerin anlamına dair önemli bir gösterge olmaktadır. Sokak isimleri, gösteren ve gösterilen olarak sosyal hayatın oluşmasında, kültürel dokunun algılanmasında ve tarihin aktarımında önemli bir rol üstlenir.

Sonuç olarak sokak isimleri; yerin tarihinden bir kesit sunarak, yerin anlamını oluşturan, doğal, mekânsal ve toplumsal yapı hakkında bilgi vererek, ölçek ve içerik açısından yeri anlamada çok önemli bir çalışma alanı haline 
gelmektedir. Bu çalışma; önerdiği bir yol haritası ile sokak isimlerini yerin anlamının araştırıcısı olarak tanımlamayı amaçlamaktadır.

\section{Sokak İsimleri İle İlgili Yapılan Çalışmalar}

Bodnar (2009) çalışmasında, 17. yüzyıldan beri Budapeşte'nin sokak isimlerinin anlamlarını incelemiştir. Çalışma, 1848 Macaristan devriminden sonra 19. yüzyılda meydana gelen sokak isimlerindeki önemli değişikliklere işaret etmekte ve sokak isimlerinin siyasi değişikliklerin belirtileri olduğuna dikkat çekmektedir. Azaryahu ve Kook (2002), Hayfa, Kudüs ve Ümm el Fahm'da Arap-Filistin kimliğini yaratmak için sokak isimlerinin etkisini incelemiştir. Üç alan, Arap-Filistin kimliğinin farklı özelliklerini göstermektedir. Light (2004), 1990 ve 1997 arasındaki sokak isimlerinin değişikliklerini incelemiş ve Bükreş'te sosyalist rejim sonrası değişimi ve ulusal kimliği göstermiştir. Bu çalışma, sokak isimlerinin yeniden isimlendirilmesinin yeni ulusal kimlik oluşturmak için önemli bir araç olduğunu göstermektedir. Costa (2012), sokak isimlerinin kentsel hafızadaki önemine dikkat çekmiştir. Çalışmasında, Barselona kenti haritasında sembolik değişiklikler üzerine bir inceleme yürütmekte ve İkinci Cumhuriyet döneminde isimlendirme sürecini açılamaktadır. Stiperski ve diğerleri (2011), sekiz Orta Avrupa Şehri; Graz, Krakow, Olomouc, Prag, Maribor, Zagreb, Zadar ve Mostar'ın tarihi çekirdeğindeki sokakların, meydanların ve parkların isimlerini incelemişlerdir. Şehir toponimlerini beş kategoriye ve on bir alt gruba ayırmışlar, 8 şehir için ilk üç toponim grubunu sıralamışlardır. Shoval (2013), İsrail'in EskiŞehri'ndeki sokak isimlerini, turizm gelişimini göz önünde bulundurarak araştırmıştır. Şehrin eski sokaklarında turistlere ve ziyaretçilere ilginç deneyimler yaratarak turizmi geliştirmek ve yerel halkın aidiyet duygusunu yaşatmak amacıyla sokak isimlendirmesinin yapılmasını önermiştir. Vasile ve Bordusanu (2014), toponomik mirası kültürel mirasın bir parçası olarak tanımlamışlar ve yerel kimliğin yapılandırılması üzerindeki gücünü vurgulamışlardır. Araştırmaları Bükreş'teki sosyo kültürel yapıyı toponomik miras aracılığıyla incelemektir. Bucher ve diğerleri (2013), Orta Avrupa bağlamında sekiz şehrin tarihi merkezindeki kentsel toponimleri analiz etmişler ve şehirlerin tarihi merkezindeki sokak, meydan veya park isimlerinin yerel, bölgesel, ulusal ve uluslararası kimliklerin göstergesi olduğunu göstermişlerdir. Aliağaoğlu ve Uzun (2011), yaptıkları çalışmada Türkiye'nin farklı coğrafi bölgelerinde yer alan 24 ilde 4825 sokak ismini inceleyerek, isimleri cumhuriyet caddeleri, şe- 
hit caddeleri, dostluk caddeleri, yer / yön tanımlama caddeleri, sayısal caddeler, önemli kişilerin isimleri caddeleri ve diğerleri olarak 7 başlık altında sınıflandırmışlardır. Bu sınıflandırmanın Türkiye'deki diğer şehirlere de uyarlanabileceğini göstermişlerdir. 2014 devriminden sonra Ukrayna'da ulusal ve bölgesel kimliğin yeniden inşası sürecinde sokaklarda yeniden isimlendirme süreci yaşanmıştır. Gnatiuk (2018) çalışmasında; bu süreçte 100.000 den fazla nüfusu barındıran 39 şehirdeki cadde ve sokakların isimlerini depolitize etmek üzere, özellikle askeri-politik olaylar ve kişilerden kaçınarak yerel/ulusal kültür ve miras ile ilgili isimlerle değiştirildiğini ortaya koymuştur. Sokak isimlendirmesinin siyaseti üzerine çalışma yapan Rusu (2019); 1829-2018 yılları arasında Sibiu (Romanya)'da sokak isimlerinin kaydını yapmış, isimlendirme ve yeniden isimlendirmedeki etnopolitik yönü vurgulamıştır.

Sokak isimleri ile ilgili yapılan bu çalışmalar daha çok baskın ideolojilerin, dönemleriyle ilgili siyasi, sosyal ve tarihsel bağlamları sokak isimlerine yansıttığını göstermektedir. Ayrıca kimlik göstergesi olarak kimlik inşasında da sokak isimlendirmenin bir araç olduğuna vurgu yapılmaktadır. Bu inceleme sonrasında, sokak isimleri özelinde, içine gömülü olan yerin doğal, mekânsal, toplumsal bileşenlerinin birbirleriyle ilişkileri üzerinden yerin anlamını araştıran bir çalışmaya rastlanmamıştır.

\section{Yöntem: Sokak İsimlerini Belgeleme Ve Analiz Etmeye Yönelik Bir Yol Haritası}

Bir kenti veya kent parçasını anlamak, o yerin bileşenlerinin birbirleriyle ilişkilerini kavramayı; doğal, mekânsal ve toplumsal çevre gibi gündelik yaşama ait katmanları çözümleyerek bunların ilişkilerini anlamayı içerir. Bir yeri anlamak, o yerin geleceğine dair tahmin yapabilmek, herhangi bir müdahalede bulunabilmek için gereken ön adımdır. Bu nedenle mimaride de yeri anlamlandırabilmek ve özünü kavrayabilmek için çeşitli yaklaşımlar geliştirilmiştir. Bu yaklaşımlar daha çok dilbilim, antropoloji, psikoloji, sosyoloji gibi disiplinlerin göstergelere dayanan göstergebilim (semiyoloji) ve yorum temelli hermeneutik yöntemleri üzerinden gerçekleştirilmiştir.

Göstergebilimin, Avrupa dillerindeki karşılığı olan semiotik (Almanca), semiotique ve semiologie (Fransızca), semiotics (İngilizce) terimleri, Eski Yunancadaki semeion sözcüğüne dayanmaktadır ve bu kelime gösterge, işaret anlamına gelmektedir (Akerson, 2016, s. 49). İlk olarak Göstergebilim'in var- 
lığını ilke olarak öne süren Saussure'e göre her türlü göstergeler dizisi gösterge bilimin konusu olmuştur ve dilbilim göstergeler biliminin ancak bir bölümünü oluşturmaktadır. Saussure'ün yapısalcı dil yaklaşımında hem gösterenler (sesler ile imler), hem de gösterilenler (düşünceler) ait oldukları özel dil dizgesinin biçimsel yapısı uyarınca anlamlarına ulaşmaktadırlar. Barthes (1993)'a göre dilbilim semiyolojinin bir alt başlığı değil kapsayıcısıdır. Dile biçtiği bu ayrıcalıklı durum Barthes'ı, yapısalcı gelenekten ziyade fenomenolojiye ve tüm yaşantının dilden kaynaklanan bir yönü olduğunu ileri süren hermeneutiğe yakınlaştırmaktadır. Barthes'a göre semiyoloji, toplumsal derinliği olan dizgeleri ele aldığında yolu mutlaka dille kesişecektir. Gösterilenler dünyasına, dilin dışında bir yer biçmeyen Barthes'ın tanımlaması, gösterge dizgeleri olarak kabul edilen dizgeleri incelemekle birlikte tüm kültür görüngülerini gösterge dizgeleriymiş gibi ele almaktadır. Bunu yaparken tüm kültür görüngülerinin gerçek yaşamda gösterge dizgeleri olduğu düşüncesinden, diğer bir deyiş̧le kültürün temelde bir bildirişim şekli olduğundan yola çıkmaktadır.

Edebiyat, karikatür, resim, toplumsal davranışlar ve sinema gibi birçok alanda eser çözümlemesinde kullanılan semiyoloji, mimaride de anlam araştırmalarında özellikle "yer" in anlamının irdelenmesi ve değerlendirilmesinde kullanılabilecek bir yöntemdir.

Hermeneutik ise, kökleri Orta Çağ'da kutsal metinleri anlamak üzerine oluşturulmuş yönteme dayanan ve "yorum bilim" olarak da Türkçeye çevrilen bir yaklaşımdır. İlk kez Alman düşünür Schleiermacher, 19.yy'ın başlarında tüm metinlere uygulanabilecek bir anlama yöntemi olarak tasarlayarak anlama sorununu evrenselleştirmiştir. Bu anlayışta dilin rolü ön plana çıkmış ve yazılı esere bağımlı kalan filolojik yorumlamanın sınırları ilkece aşılmak istenmiştir (Grondin, 2017, s. 7-41; Gadamer, 1995, s. 9-28). Dilthey, filolojik yorumlama sanatının tarihinden başlayarak, bir açımlama öğretisi olarak hermeneutiğin niteliğini araştırmaya çalışmıştır (Bollnow, 1995, s. 83-122). Dilthey (1999) altı ilke ortaya koymaktadır. Anlamanın; duyusal olarak, işaretler aracılığıyla, yazı yoluyla, ilgiye bağlı olarak, yaşanmışlıklar aracılı̆̆ıyla gerçekleşebileceğinin ve yöntemsel analizinin gerekliliğinin altını çizmiştir. Heidegger (1926/2004) ise, birçok hermeneutik tarihçisine göre, çağdaş hermeneutik çalışmalarına yön veren en önemli isimdir. Heidegger, geleneksel hermeneutikçilerin aksine hermeneutiği ontolojik temelli anlayış ile ele almıştır. Hermeneutik burada fenomenoloji yaklaşımıyla insan varlığının açıklanmasını anlatmaktadır. Geleneksel hermeneutiği eleştirerek bir anlamda çağ- 
daş hermeneutiğin kurucusu sayılan Gadamer (1960/2008)'in bakış açısı, nedenlerle ya da yasalar sistemiyle değil, bir bütünün parçaları açısından ve bu bütünün parçalarını da bütünün anlamına yaptıkları katkı açısından anlamaya çabalamanın döngüsel süreciyle ilgilidir.

Sokak isimleri aracılığıyla yapılacak olan bu çalışmada yere ait göstergelerin tespit edilmesinde kullanılacak yöntem göstergebilimdir. Sokak isimlerinin anlamı, konumu, dönemi, isimlendirme sürecinde sokak ismini öneren taraflar, karar verme kurumu, uygulayıcı ve uygulama araçları, her biri birer gösterge dizgesidir. Bu göstergeler bir araya getirilecek ve bunların arkasındaki anlam yorumlanarak sokak isimlerinin anlamına ulaşılacaktır. Yorumlama aşamasında kullanılacak yöntem hermeneutiktir. Daha sonra sokak isimlerinin anlamında yerin özelliklerini işaret eden göstergeler ayrıştırılacak ve yerin anlamına ulaşılacaktır. Böylece sokak isimleri içinde gömülü olan anlam, göstergelere dayanan semiyoloji ve yorum temelli hermeneutik yöntemlerden yararlanarak göstergeler ve bileşenler aracıllğ̆ıla keşfedilecektir. Bu çalışma sınırları belirlenmiş bir alanda yapılacaktır. İzlenecek yol 3 aşamadan oluşmaktadır. Birinci aşama, sokak isimlerine dair göstergelerin elde edilmesi; ikinci aşama, her sokak için bu göstergelerin kayıt altına alındığ1 "Sokak İsim/İsimleri Bilgi Kartı"nın tasarlanması ve oluşturulması, üçüncü aşama ise sokak isimlerinden üretilen göstergeler aracıllğ̆ıla bütüne dair o yeri anlamadır. Şekil 1'de aşamaları gösteren yol haritasına yer verilmektedir.

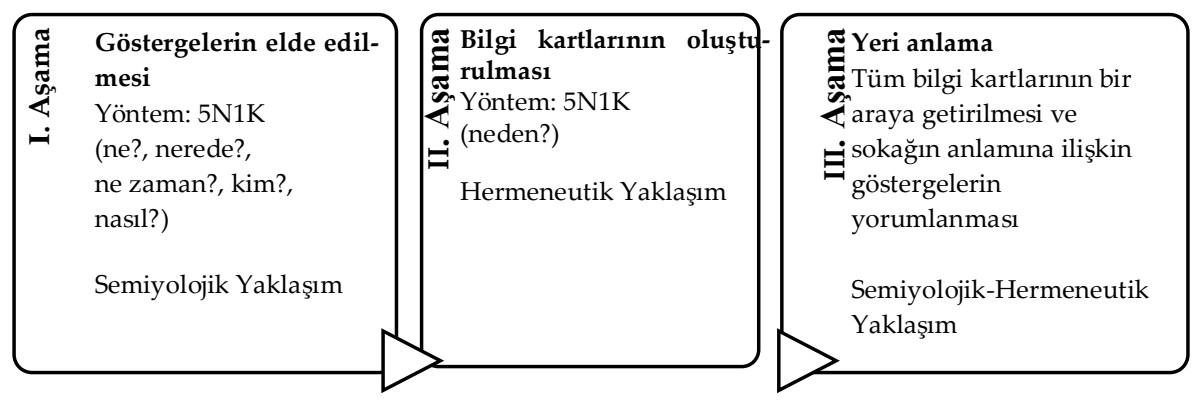

Şekil 1. Yer'i sokak isimleri aracılığıyla anlamak için yol haritası

\section{Aşama - göstergelerin elde edilmesi}

Anlam araştırıcı yöntemlerden biri olan ve göstergelere dayanan semiyoloji çerçevesinde bilgi üretmek için bu çalışmada sokak isimlerine, ayrıntılı düşünme olanağı veren $5 \mathrm{~N} 1 \mathrm{~K}$ soruları ile yaklaşılmıştır. $5 \mathrm{~N} 1 \mathrm{~K}$ yönteminde konuya işaret eden "Ne?" sorusunun cevabı, sokak ismini; mekân ve yer kav- 
ramlarına işaret eden "Nerede?" sorusunun cevabı, sokağın fiziksel konumunu; süreç kavramına işaret eden "Ne zaman?" sorusunun cevabı ise, sokağın ismini aldığı dönemini belirtmektedir. İlgili ve sorumlu kişilere işaret eden "Kim?" sorusunun cevabı, sokak ismini öneren taraftarları (topluluk, yerel makamlar, STK'lar ve diğerleri), karar verme kurumunu ve uygulay1cıyı (belediye); yönteme işaret eden "Nasıl?" sorusunun cevabı ise, uygulama araçlarını göstermektedir. Böylece öncelikle çalışma alanında bulunan sokaklar için; sokak ismi, sokağın fiziksel konumu, sokağın ismini aldığı dönemi, sokak ismini öneren taraftarları, karar verme kurumunu ve uygulayıcıyı, uygulama araçlarını gösteren göstergeler elde edilir ve ön inceleme gerçekleştirilir.

Göstergelerin veri kaynaklarl; yerel yönetim arşivlerinden elde edilecek dönemsel haritalar, sokak isimleri ile ilgili belediyenin meclis kararları, alan çalışması, yerel otorite ve yerel halkla yapılan görüşmeler, literatür araştırmaları ve alan araştırmasından elde edilen görüntüler, videolar ve belgelerdir.

\section{Aşama - bilgi kartlarnnın oluşturulması}

$\mathrm{Bu}$ aşamada, her sokak için elde edilen göstergeler yorumlanarak 5N1K yönteminde amaca işaret eden "Neden?" sorusunun cevabı ile, sokak ismindeki anlama ulaşılır. Sokak ismindeki anlam, semiyoloji aracıllğıyla belirlenen göstergelerin, hermeneutik yaklaşım ile yorumlanmasıyla ortaya konur. Anlam, yerin doğal, mekânsal ve toplumsal bileşenlerini içerir. Göstergeler ve elde edilen sokağın anlamının yer aldığı bilgi kartı tasarımı yapılır ve böylece her sokak için bilgi kartları üretilir. Bilgi kartlarında yer alan sokağın anlamı, o yeri anlamak için üretilen yeni göstergeleri barındırır.

\section{Aşama - yeri anlama}

Sokak bilgi kartları aracılığıyla her bir sokağın anlamından üretilen yeni göstergeler bir araya getirilir. Bu aşamada araştırmacıya kılavuzluk edecek bileşenler ve örnek göstergeleri Tablo 1'de verilmektedir. 
Tablo 1. Yer'in bileşenleri ve örnek göstergeleri (Kaynak: Yazarlar tarafından oluşturulmuştur)

\begin{tabular}{ll}
\hline YERIN BİLEŞENLERİ & ÖRNEK GÖSTERGELER \\
\hline DOĞAL & -ïklimsel (rüzgar, güneşlenme, ...) \\
& -Topografik (eğim durumu, yükseklik,...) \\
& -Botanik (ağaçlar, bitkiler, çiçekler....) \\
& -Coğrafya (dereler, dağlar,...) \\
\hline MEKÂNSAL & -Yerleşim yeri (kent,...) \\
& -Kamusal alanlar (çeşmeler, camiler, hamamlar, mey- \\
& danlar, pazar alanları,...) \\
\hline TOPLUMSAL & -Yerel isim (vali,, muhtar, tüccar,...) \\
& -Ulusal isim (Başbakan, milletvekili, komutan,...) \\
& -̇̇ş (dükkanlar, firın,...) \\
& -Meslek (eski meslekler,...) \\
\hline DİĞER & - Sıfatlar (güzel, beşinci,...) \\
\hline
\end{tabular}

Sokak isimlerinde gömülü olan göstergeler aracılı̆̆ıyla bölge kapsamında yerin anlamı tarihsel perspektif içinde yorumlanarak ortaya konur. Bu aşamada semiyolojik ve hermeneutik yaklaşımlar bir arada kullanılır.

\section{"Yer" i Sokak İsimleri Aracılığıyla Anlamaya Yönelik Bir Çalışma: İzmit/Akçakoca Tarihi Bölgesi}

Çalışma alanı olarak belirlenen Akçakoca tarihi bölgesi Kocaeli ilinin İzmit ilçesi sınırlarında yer almaktadır. İsmi Osmanlı İmparatorluğu döneminde bölgeyi fetheden Akçakoca Bey'den gelmektedir. Akçakoca Bey, Ertuğrul Gazi, Osman Gazi ve Orhan Gazi ile Kocaeli ve Sakarya bölgelerinde baskınlar yapmış, ancak kentin fethinden önce, 1328'de hayatını kaybetmiştir. Akçakoca bölgesi, kentin Osmanlı İmparatorluğu tarafından fethinden sonra bulunan ilk yerleşim yerlerinden biridir.

Akçakoca tarihi bölgesi İzmit Kent Merkezi'nin kuzeyinde konumlanmakta, batıda Kozluk ve Turgut mahallelerinden koruma alanına sınır oluşturan Saadettin Yalım Caddesi, kuzeyde Orhan Mahallesi'nden Orhan Caddesi ve Hasan Elbeyoğlu Sokak, doğuda Veliahmet Mahallesi'nden Hacı Hürrem Yokuşu, güneyde Hacıhasan Mahallesi'nden doğu-batı doğrultusunda Çukurçeşme Sokak ve kuzey doğrultusunda Sırrıpaşa Caddesi, güneyde Kemalpaşa Mahallesi'nden İnönü Caddesi ile ayrılmaktadır. Akça- 
koca tarihi bölgesi günümüzde 20 sokaktan oluşmaktadır. İzmit Kent Merkezi'ndeki ve Kentsel Sit Alanı içerisindeki konumu Şekil 2a'da, silüet olarak konumu da Şekil 2b'de gösterilmektedir.
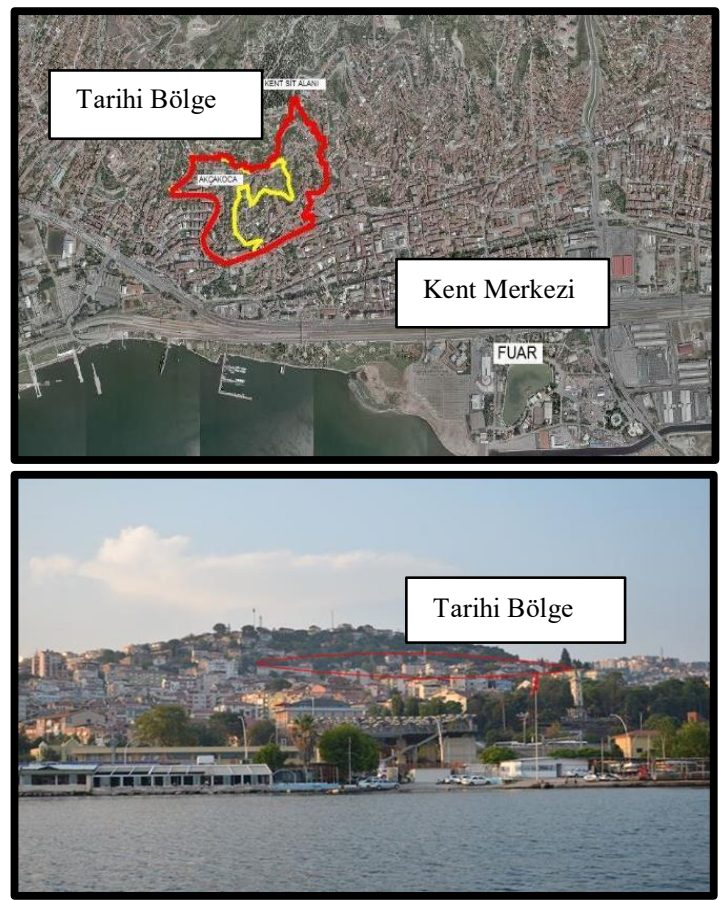

Şekil 2. Çalışma alanının İzmit Kent Merkezi'ndeki (a) ("Kocaeli Rehber", t.y.) ve siluet içindeki (b) (Ertürk, 2019) konumu

Yerin anlamına ilişkin göstergelerin elde edilmesi için öncelikle Türkiye'de sokak isimlendirme sürecini anlamak gerekmektedir. Ülkemizde sokak isimlendirme sürecinde yetkili kurumlar çeşitli yasa ve mevzuatlarla tanımlı hale gelmiştir. Büyükşehir Belediyesi statüsüne sahip illerde; 5216 sayılı Büyükşehir Belediyesi Kanununun 3.Bölüm Büyükşehir Belediyesinin görev yetki ve sorumlulukları başlı̆̆ı altında g bendinde "....meydan, bulvar, cadde, yol ve sokak ad ve numaraları ile bunlar üzerindeki binalara numara verilmesi işlerini gerçekleştirmek" ifadesiyle günümüzde sokak isimlendirme yetkisi büyükşehir belediyelerine verilmiştir. Diğer illerde ise; 5393 sayılı Belediye Kanununun ikinci kısım Belediye Organlarının, Belediye Meclisinin görev ve yetkilerini anlatan 18. Maddesinin n bendinde "Meydan, cadde, sokak, park, tesis ve benzerlerine ad vermek..." ifadesiyle yetki il belediyelerine verilmiştir. Buna bağlı olarak, bölge sakinlerinden, muhtarlardan veya ilçe belediyelerinden gelen talepler üzerine konu belediye meclisleri 
tarafından ilgili komisyonlarca incelenir. Komisyon tarafindan hazırlanan rapor meclise sunulur ve meclis üyeleri tarafından kabul veya ret edilir. Bu süreçte ulusal veya yerel ölçeklerde meydana gelen toplumsal, politik, ekonomik değişimler de sokak isimlendirmelerine yön vermektedir (MBS 2016a, 2016b).

Çalışma bölgesindeki sokak isimlerinin, ne, nerede, ne zaman, nasıl ve kim sorularının cevabına ilişkin veriler için günümüzde bölgeden sorumlu belediye arşivlerinden periyodik haritalar ve çalışma alanı sınırı içinde bulunan sokakların isimlendirme kararları temin edilmiştir. Harita ve belgelerden elde edilen veriler saha çalışmaları aracılığıyla güncel durum ile karşılaştırılmıştır. Toplanan veriler yerel makamlar ve kişilerle görüşülerek kontrol edilmiştir. Literatür incelemelerinden ve saha çalışmalarından fotoğraflar, videolar ve belgeler sağlanmıştır. Ön inceleme sonucunda, Akçakoca tarihi bölgenin 20 sokaktan oluştuğu (Şekil 3) görülmektedir.

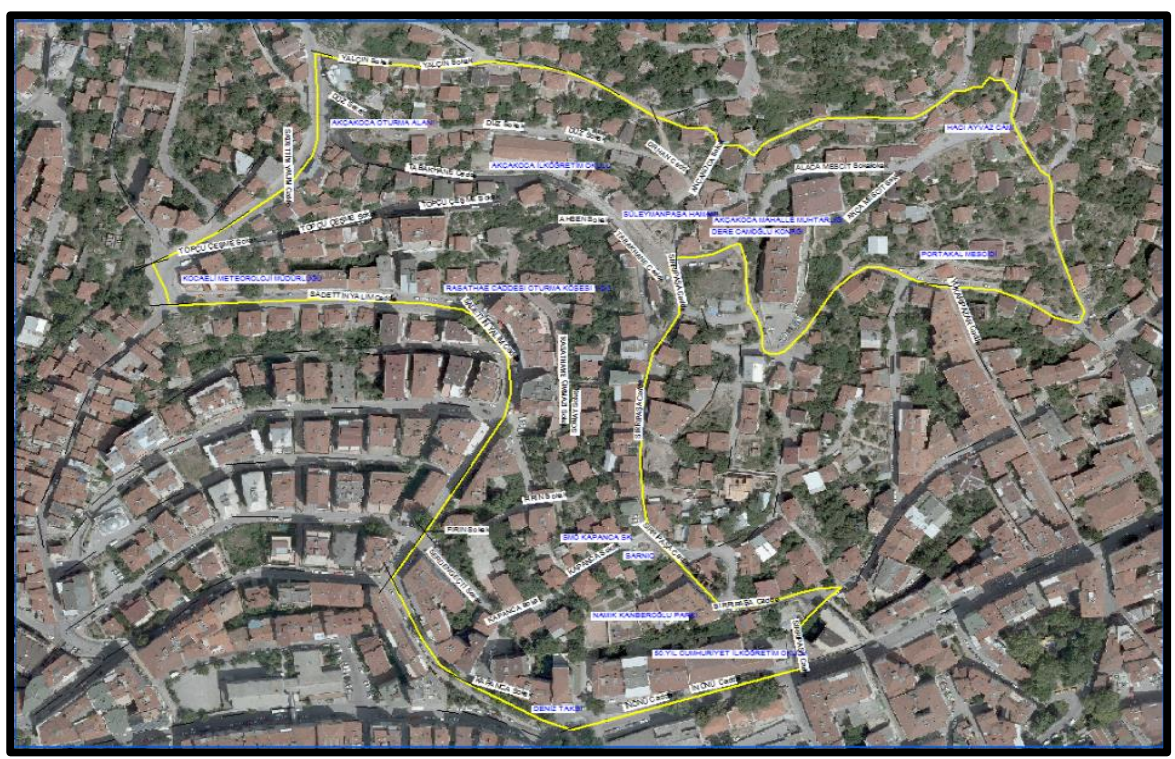

Şekil 3. Akçakoca mahallesi sokakları ve isimleri ("Kocaeli Rehber", t. y.) 


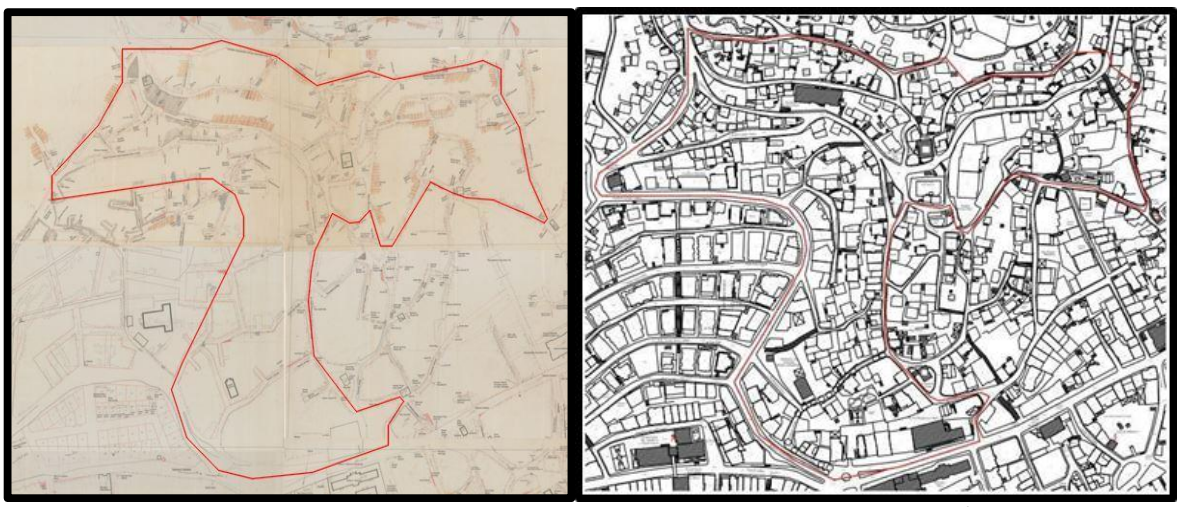

Şekil 4. Akçakoca tarihi bölge sınırları ve dokusu (1925) (a) ve (2020) (b) (İzmit Belediyesi, t.y.)

Çalışma alanına dair en eski 1925 Osmanlıca İstikamet planları (Şekil 4a) ve 2020 hâlihazır haritaları (Şekil 4b) incelendiğinde, fiziksel dokusu önemli ölçüde değişmemiştir. Ancak bu haritalara ek olarak diğer haritalar ve meclis kararları da incelendiğinde, sokak isimlerinin dönemsel olarak değişiklik gösterdiği anlaşılmıştır (Tablo 2). Bu değişikliklere bağlı olarak dört zaman kesiti tespit edilmiştir. Bunlar; başlangıç olarak bölgedeki sokak isimlerinin istikamet planlarından okunabileceği 1925, sokak isimlerinin en çok değiştiği 1965 ve 1995 ile günümüzdeki durumu ifade eden 2020 tarihleridir.

Tablo 2. Akçakoca Mahallesi sokak isimlerinin 1925-2020 yılları arası değişimi (Kaynak: Yazarlar tarafından oluşturulmuştur)

\begin{tabular}{|c|c|c|c|c|}
\hline & 1925 & 1965 & 1995 & 2020 \\
\hline \multirow[t]{2}{*}{1} & & & & Rasathane \\
\hline & & & 6.Cadde & Çıkmazı \\
\hline \multirow[t]{2}{*}{2} & Dere Camii Şerifinden & Düzyol & & \\
\hline & Kandilliye Giden Yol & Sokak & Düz Sokak & Düz Sokak \\
\hline \multirow[t]{2}{*}{3} & Yukarı Pazardan Aynalı & Topçu Çeşme & Topçu Çeşme & Topçu Çeşme \\
\hline & Kavak'a Giden Cadde & Sokak & Sokak & Sokak \\
\hline \multirow[t]{7}{*}{4} & Hacı Ayvaz Camii Şerifinden Yukarı Gi- & & & \\
\hline & den YolHacı Ayvaz Camii Şerifinden Yu- & & & \\
\hline & karı Beldelere Giden Yol Hacı Ayvaz Ça- & & & \\
\hline & maşırlığından Acı Çeşmesine Giden $Y$ & & & \\
\hline & Alaca Mescidinden Acı Çeşmesine & & & \\
\hline & Giden Taşlı Yol Alaca Mescid Şerifinden & Alaca Mescid & & Alaca Mescid \\
\hline & Hacı Ayvaz Camii Şerifine Giden Yol & Sokak & Alaca Mescid Sokak & Sokak \\
\hline \multirow[t]{2}{*}{5} & & Akça Mescid & & Akça Mescid \\
\hline & Tekke Bahçesi Sokağı & Sokak & Akça Mescid Sokak & Sokak \\
\hline \multirow[t]{4}{*}{6} & & Yeni Hamam & & \\
\hline & & Sokak & & \\
\hline & Zeytinci Sokağı & Portakal Mes- & & Çukurçeşme \\
\hline & Kara Bayırı Sokağı & cidi Geçidi & Çukurçeşme Sokak & Sokak \\
\hline \multirow[t]{2}{*}{7} & & İstanbul & & \\
\hline & İstanbul Caddesi & Caddesi & İnönü Caddesi & İnönü Caddesi \\
\hline
\end{tabular}




\begin{tabular}{|c|c|c|c|c|}
\hline \multirow[t]{2}{*}{8} & \multirow[b]{2}{*}{ Erik Dibi Sokağı } & \multicolumn{2}{|l|}{ Bağçeşme } & \multirow{2}{*}{$\begin{array}{l}\text { Saadettin } \\
\text { Yalım Caddesi }\end{array}$} \\
\hline & & Caddesi & Rasathane Caddesi & \\
\hline 9 & & İnciraltı & & \\
\hline & Hamam Sokağı & Sokak & Akçakoca Sokak & Akçakoca Sokak \\
\hline 10 & & Sirn Paşa & & \\
\hline & Sepken Bayırı & Sokak & Sırrı Paşa Sokak & Sırrı Paşa Sokak \\
\hline 11 & & Orhan & & \\
\hline & Orhan Caddesi & Caddesi & Orhan Caddesi & Orhan Caddesi \\
\hline 12 & Hacı Ayvaz Sokağı & $\begin{array}{l}\text { Hacı Hürrem } \\
\text { Yokuşu }\end{array}$ & $\begin{array}{l}\text { Hacı Hürrem } \\
\text { Yokusu }\end{array}$ & $\begin{array}{l}\text { Hacı Hürrem } \\
\text { Yokuşu }\end{array}$ \\
\hline 13 & $\begin{array}{l}\text { Bozoklu Meydanlığından } \\
\text { Yukarı Pazara Giden Yol }\end{array}$ & $\begin{array}{l}\text { İnciraltı } \\
\text { Sokak }\end{array}$ & $\begin{array}{l}\text { Hasan } \\
\text { Elbeyoğlu Sokak }\end{array}$ & $\begin{array}{l}\text { Hasan Elbeyoğlu } \\
\text { Sokak }\end{array}$ \\
\hline 14 & $\begin{array}{l}\text { Yukarı Pazardan Kandilli } \\
\text { Camii Șerifine Giden Yol }\end{array}$ & $\begin{array}{l}\text { Tabakhane } \\
\text { Caddesi }\end{array}$ & Tabakhane Caddesi & $\begin{array}{l}\text { Tabakhane } \\
\text { Caddesi }\end{array}$ \\
\hline 15 & Fehimoğlu Sokağg & Fırın Sokağı & Firın Sokak & Firın Sokak \\
\hline 16 & & Kapanca & & \\
\hline & Kapancı Sokağı & Sokak & Kapanca Sokak & Kapanca Sokak \\
\hline 17 & & & Serdengeçti Sokak & Serdengeçti Sokak \\
\hline 18 & & & Salkım Sokak & Sonay Sokak \\
\hline 19 & Hacı Kirkor Sokağ1 & Güzel Sokak & Serin Sokak & Ahsen Sokak \\
\hline 20 & & Orhan & & \\
\hline & Çakmakçı Sokağı & Caddesi & Yalçın Sokak & Yalçın Sokak \\
\hline
\end{tabular}

Akçakoca tarihi bölgesinde günümüzde yer alan 20 sokağın isimleri 95 yıllık süreç içerisinde değişiklik göstermiş ve bölgede 48 sokak ismi tespit edilmiştir. 1925-2020 arası süreç içerisinde Kapanca Sokak ve Orhan Caddesi olmak üzere sadece 2 sokağın isminin korunduğu, 1925 ve 1965 zaman kesitlerinde İstanbul Caddesinin isminin değişmediği, 1965-2020 arası 55 yıllık dönem içerisinde, Düz Sokak, Topçu Çeşme Sokak, Alacamescid Sokak, Akçamescid Sokak, Sırrı Paşa Caddesi, Hacı Hürrem Yokuşu, Tabakhane Caddesi ve Fırın Sokak olmak üzere 8 sokağın isminin değişmediği, 1995-2020 arası 25 yıllık dönem içerisinde, Çukurçeşme Sokak, İnönü Caddesi, Akçakoca Sokak, Hasan Elbeyoğlu Sokak, Serdengeçti Sokak ve Yalçın Sokak olmak üzere 6 sokağın isminin korunabildiği ve son dönemde ise Rasathane Çıkmazı, Saadettin Yalım Caddesi, Sonay Sokak ve Ahsen Sokağın günümüze kadar sürekli değişerek geldiği tespit edilmiştir (Tablo 2).

Sokak isimlerini bölgede uygulama aracı Akçakoca Muhtarlığıdır. Öneren ve uygulayan ise dönemsel farklılıklar göstermektedir. Bölgeden sorumlu kurum 1965 yılında İzmit Belediyesi iken, 1995 yılında bu durum değişmiş ve Saraybahçe Belediyesi olmuştur. Ancak 2009 yılında il bazında yapılan çalışma sonucu belediyelerin birleşmesi nedeniyle, belediye sorumluluk alanları ve yetki sınırları değişmiş, bu değişim ile oluşan yeni İzmit Belediyesi bölgedeki sokak isimlerinin değişikliğinden sorumlu kurum haline gelmiştir ve günümüze kadar bu durum devam etmektedir. 
Yeri anlamak için öncelikle sokağı anlamak gerekmektedir. Bir önceki aşamada elde edilen veriler ve ön değerlendirme ile ulaşılan bilgiler aracıllğıyla 'neden' sorusunun cevabı yerin üç bileşeni olan doğal, mekânsal ve toplumsal başlıkları altında yorumlanarak sokağın anlamına ulaşılmış ve tüm bu bilgiler sokak isimleri için tasarlanan bilgi kartlarında toplanmıştır. Her sokak için düzenlenen bilgi kartlarından her dönem sürekli ismi değişen Saadettin Yalım Caddesi Şekil 5(a) ile 95 yıllık süreç boyunca ismi değişmeyen Kapanca Sokak Şekil 5(b) bilgi kartı örneklerine aşağıda yer verilmektedir.
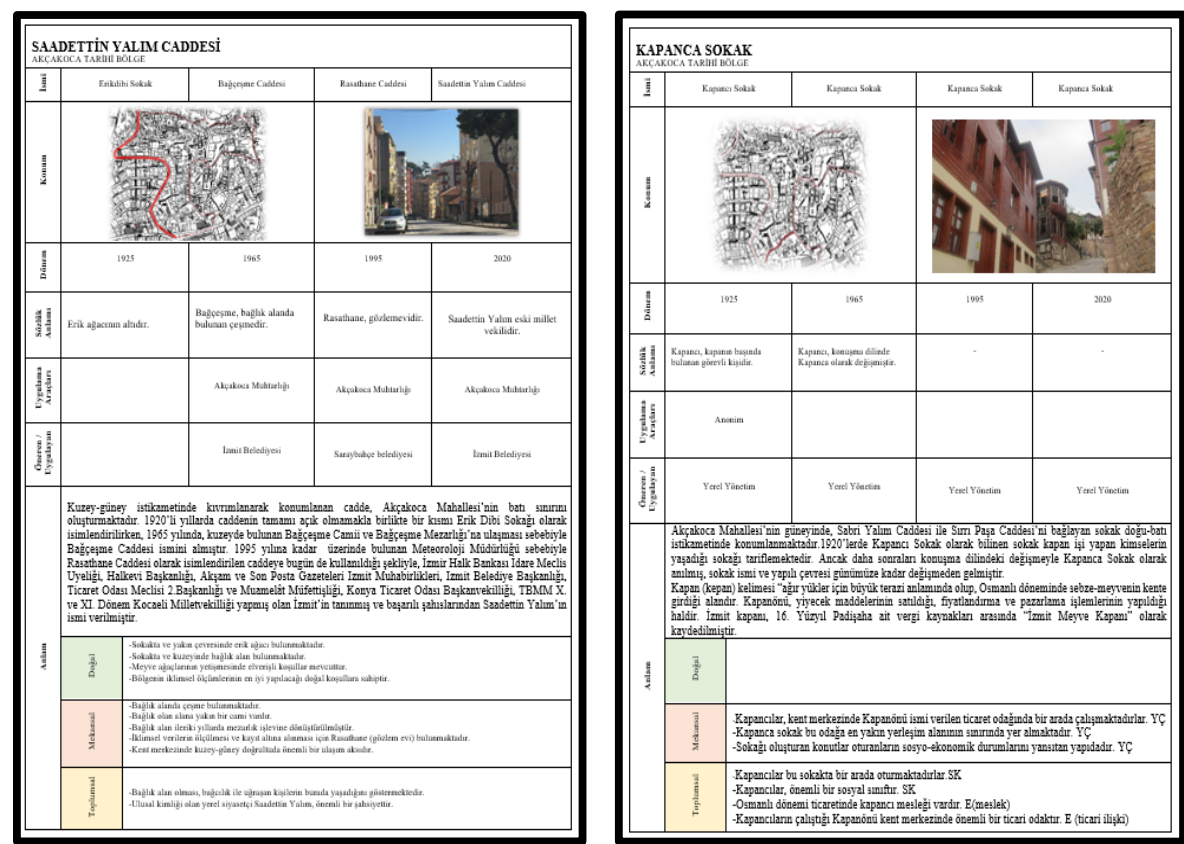

Şekil 5. Sadettin Yalım Caddesi Bilgi Kartı(a) ve Kapanca Sokak Bilgi Kartı(b) (Kaynak: Yazarlar tarafından oluşturulmuştur)

Yeri (İzmit/Akçakoca Tarihi Bölge) anlamak için zaman kesitlerine yönelik genel değerlendirmenin ardından doğal, mekânsal, toplumsal bileşenler bağlamında her bir sokağın anlamından üretilen yeni göstergeler bir araya getirilerek yorumlanmıştır.

İzmit/Akçakoca Tarihi Bölgesi, sokak isimlerindeki değişiklikler, genellikle ulusal politik eğilimleri ve hedefleri göstermektedir. Özellikle Türk Kurtuluş Savaş'ndan (1919-1923) ve yeni Türkiye Cumhuriyeti'nden (1923) sonra ülke çapında yeniden yapılanma dönemi başlamış ve bu dönemde stratejiler ağırlıklı olarak mekânsal çevrenin yapılanmasına yönelik geliştirilmiştir. Belediyeler Yasasi'ndaki (1930) düzenlemeler ile resmi kentsel isimlendirme 
başlamış ve sonuç olarak mekânı ifade eden sokak isimleri 1925-1965 döneminde daha popüler hale gelmiştir. Diğer yandan, 1960, 1971, 1980 darbeleri sokak adlarını da etkilemiş, bu nedenle toplumsal özellikler, özellikle ulusal ve yerel öneme sahip kişi isimleri 1965'den 1995 e kadar olan dönemde daha yaygın kullanılmıştır. 1995 yılından sonraki isimlendirme değişiklikleri ise yer ile bağlamı olmayan şekilde yapılmıştır.

Yeri anlamak için öncelikle her bir sokağın anlamından iklimsel, topoğrafik, botanik, jeolojik olmak üzere 4 adet doğal; yerleşim yeri, kamusal alanlar, ticaret alanları, özel alanlar ve kentsel ögeler olmak üzere 5 adet mekânsal; yerel isim, ulusal isim, iş, meslek olmak üzere 4 adet toplumsal ve sıfat olmak üzere 1 adet diğer başlıklarında göstergeler üretilmiştir. Buna göre bölgede sokak isimleri bilgi kartlarından üretilen yerin anlamına ilişkin 86 adet gösterge tespit edilmiştir (Ek 1). Şekil 6'da bu göstergelerin oransal dağılımı verilmektedir.

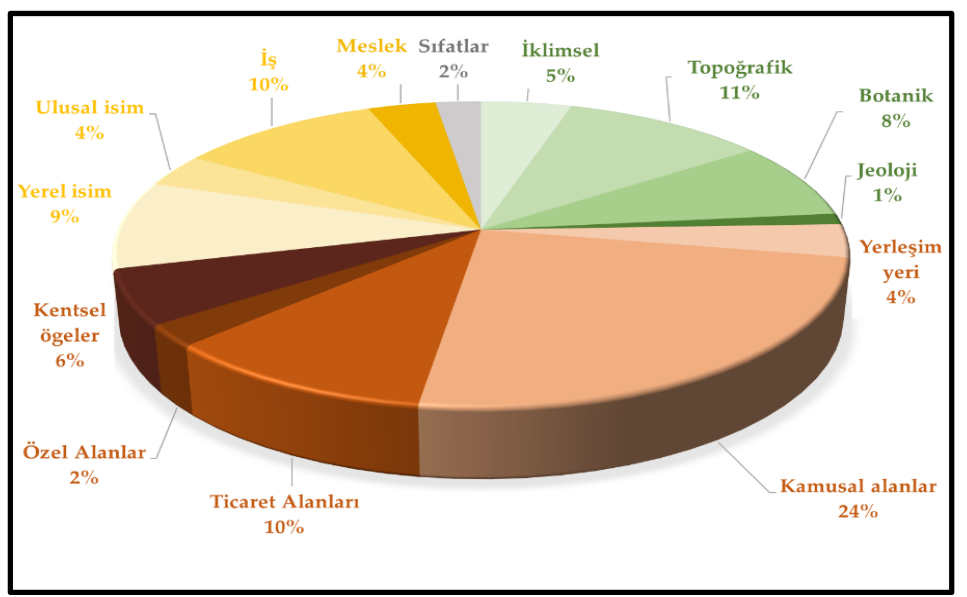

Şekil 6. Sokak isimleri anlamından elde edilen yere ait göstergelerin dağılımı (Kaynak: Yazarlar tarafından oluşturulmuştur)

Akçakoca tarihi bölgesinin sokak isimlerinin anlamından üretilen göstergelerin \%47 si yerin mekânsal bileşenini, \%27'si yerin toplumsal bileşenini, \%24'ü yerin doğal bileşenini ifade etmektedir. Bölgenin mekânsal olarak çok güçlü olduğu, toplumsal ve doğal özellikleri açısından da yakın bir oran gösterdiği anlaşılmıştır. Bu göstergelerin yorumlarından ulaşılan anlam aşağıda verilmektedir. 


\section{Bulgular: Yerin (Akçakoca Tarihi Bölge) Anlamı}

\section{Yerin doğaya ilişkin anlamı}

Bölge, kuzey güney aksında dik bir eğime sahiptir (Kara Bayırı Sokak Şekil 7a, Çukurçeşme Sokak). Doğu batı aksında ise düz bir topoğrafya hâkimdir (Düz Sokak Şekil 7b).
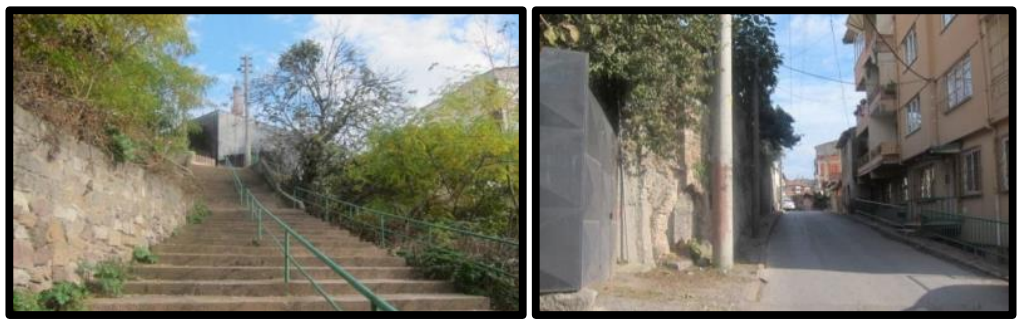

Şekil 7. Kara Bayırı Sokak (a) ve Düz Sokak (b) (Ertürk, 2019)

Bölgede yer alan gözlem merkezi, iklimsel verilerin en iyi okunabileceği konumun bu bölge olduğunu ifade etmektedir (Rasathane Caddesi). Güneye doğru inen bir yamaç üzerinde bulunan bu bölgede rüzgâr ve yağış verileri günümüzde de güvenilir bir biçimde tespit edilmektedir. Bölgenin topoğrafyası eğimli, mikrokliması yağış alan ve rüzgâra açık bir yapıya sahiptir (Sepken ve Serin Sokak).

Bölge birçok ağacın yetişmesine elverişli toprak ve alanlara sahiptir. 1920'lerde bölgenin batı kesimlerinde kavak ağacı yetiştirmeye elverişli alanlar mevcuttur (Yukarı Pazar'dan Aynalı Kavak'a Giden Yol). Bölgenin doğu kesimlerinde zeytin ve incir, doğu ve batı kesimlerinde erik ağaçları olduğuna dair bilgilere ulaşılmıştır (Erik Dibi Sokak, İnciraltı Sokak). Salkım bitkisinin de yetiştiği ve mekânı zenginleştirdiği de anlaşılmaktadır (Salkım Sokak). Kuzeyindeki alanların bağlardan oluşması ise bölgenin meyve ağaçlarının yetişmesine elverişli koşullara sahip olduğunun göstergesidir (Bağçeşme Caddesi). Bölgenin batısına komşu alanlarda tabakhane olması 1920'lerde hayvancılıkla uğraşıldığını, bölgede deri üretimi sağlayan hayvanların varlığını göstermekte ve bölgenin doğasının buna elverişli olduğunu ifade etmektedir (Tabakhane Caddesi). Ancak hızlı ve plansız kentleşme sonucu bahsedilen bitkisel yapı bozulmuştur.

1920'lerde taş kaplama yolların varlığ ise bölgenin jeolojik durumu hakkında bilgi vermektedir. Toprak yapısı meyve ağaçlarının yetişmesine elverişli olduğu kadar bünyesinde kayalık bir yapıyı da barındırmaktadır. 


\section{Yerin mekâna ilişkin anlamı}

Akçakoca tarihi bölgesi, kent merkezine yakın bir konumda ve İstanbul ticaret aksı üzerinde bulunmaktadır. İstanbul yönünü gösteren sokakların bu bölge içinde bulunması konum olarak bölgenin kentin batısında yer aldığının ifadesidir (İstanbul Caddesi). Türkiye'nin en büyük ili İstanbul, tarihi bölgeye $90 \mathrm{~km}$. mesafede yer almaktadır. Tarihi bölgenin kuzeyinde tarihi geçmişi olan bir mahalle de bulunmaktadır (Orhan Caddesi).

Akçakoca tarihi bölge farklı dönemlerde inşa edilmiş birçok önemli yapıya ev sahipliği yapmaktadır. Özellikle Osmanlı dönemine ait olan bu eserlerden camiler (Alaca Mescid Sokak, Akça Mescid Sokak, Portakal Mescidi Sokak, Dere Camii'nden Kandilli Camii Şerifi'ne giden Sokak, Hacı Ayvaz Camii Şerifi'nden Yukarı Pazara Giden Sokak, Yukarı Pazar'dan Kandilli Camii Şerifi'ne Giden Sokak), Osmanlı toplumunda önemli bir kültür ve eğitim alanı olan tekke (Tekke Bahçesi Sokak), çeşmeler (Topçu Çeşme Sokak, Çukurçeşme Sokak, Bağçeşme Yolu, Yukarı Pazar'dan Aynalı Kavak'a Giden Yol), hamam (Hamam Sokak, Yeni Hamam Sokak), konak ve konutlardır (Hasan Elbeyoğlu Sokak, Sırrı Paşa Caddesi). Bölgede bulunan camiler, Dere Camii, Alaca Mescid, Akça Mescid ve Hacı Ayvaz Camii günümüzde de kullanılan yapılardır. Alaca Mescid (Şekil 8a) kırmızı tuğladan inşa edilmiştir ve ismini renginden almaktadır. Akça Mescid'in ismi ise komutan Akçakoca Bey'den gelmektedir. 1920'lerde var olan Kandilli Camii maalesef varlığını koruyamamıştır. Orhan Camii ve Portakal Mescidi ise bu bölgenin yakın çevresinde bulunan ve günümüzde de kullanılan camilerdir. Orhan Camii 1332 yılında Orhan Bey'in oğlu Şehzade Süleyman Paşa tarafından ilçede yaptırılmıştır. Cami, Kocaeli'nin en eski Osmanlı binasıdır.1920'lerde mevcut olan Aynalı kavak çeşmesi, Topçu çeşme, Acı çeşme ve Çukur çeşmelerden ise sadece Topçu çeşme (Şekil 8b) yapısal anlamda korunmuş ancak fonksiyonel anlamda işlevini yitirmiştir. Bölge sınırını oluşturan hat üzerindeki Aynalı kavak çeşmesi 1925-1965 yılları arasındaki imar faaliyetleri sırasında bu hat ana ulaşım aksına dönüştürülürken kaldırılmıştır. Bölgenin kuzeyinde 1920'lerde var olduğu düşünülen Bağçeşme günümüzde bulunmamaktadır. Dere Camii'nin yanında bulunan Süleyman Paşa Hamamı (Şekil 8c) ise günümüzde restore edilerek halkın kullanımına açılmıştır. 

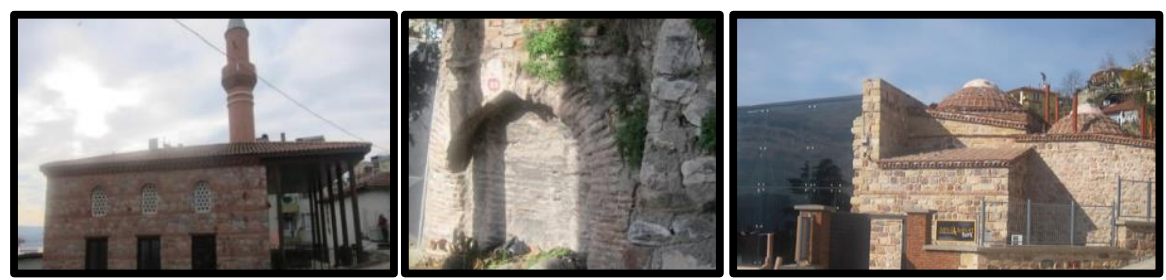

Şekil 8. Alaca Mescid (a), Topçu Çeşme (b) ve Süleyman Paşa Hamamı (c) (Ertürk, 2019)

Bölgenin kent merkezine yakınlı̆̆1 dolayısıyla 1920'lerde mevcut olan Pazar yeri (Yukarı Pazar'dan Aynalı Kavak’a Giden Yol, Yukarı Pazar'dan Kandilli Camii Şerifi'ne Giden Yol) günümüzde sokak pazarı şeklinde aynı mevkide işlevini devam ettirmektedir. Pazar yeri, Dere camii ile komşu olan hamam ise Akçakoca tarihi bölgenin merkezini bu üç yapının oluş̧turduğunun ifadesidir. Günümüzde de mevcut olan hamam ve camii bölgenin merkezi olma özelliğini devam ettirmektedir. Bu yapıların batısında bulunan Elbeyoğlu Konağı (Şekil 9a) ise Osmanlı döneminde konut ve ticaret işlevlerinin bir arada kullanıldığı bir plan tipini sergilemektedir (Hasan Elbeyoğlu Sokak). Konak planında dükkân, zemin kat sağ köşede yer almaktadır. Bu mekâna hem dişarıdan, hem de içeriden erişmek mümkündür. Konut ve ticaret bir arada tasarlanmıştır. Bu konak günümüzde de muhtarlık ofisi olarak kullanılmaktadır.
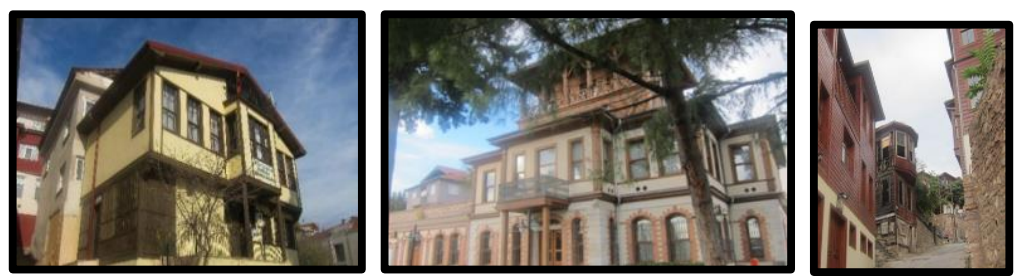

Şekil 9. Elbeyoğlu Konağı (a), Sırrı Paşa Konağı(b) ve Kapanca Konutları(c) (Ertürk, 2019)

Dönemin valisi kendisinin de proje ve inşaatında yer aldığı ve bu sokağa çok yakın bir mevkide inşa ettiği konakta (Sırrı Paşa Caddesi) iskân etmiştir. Konak (Şekil 9b) hem geleneksel Osmanlı konak tipolojisini yansıtmakta hem de dönemin Avrupa mimarisinde kullanılan motif ve malzemeleri barındırmaktadır. Günümüzde restore edilip müze olarak halkın ziyaretine açılan Sırrı Paşa Konağı bölgenin önemli bellek mekânları arasındadır. Bölgenin güneyinde kent merkezine kapan işi yapan kapancılar, kent merkezinde Kapanönü ismi verilen ticaret odağında bir arada çalışmaktadırlar. Kapan, Osmanlı kentlerinde yiyecek maddelerinin satıldığı, fiyatlandırma ve pazar- 
lama işlemlerinin yapıldığı hâldir. Kapanca sokak bu odağa en yakın yerleşim alanının sınırında yer almaktadır. Kapan işi yapan kimselerin oturduğu sokakta bulunan konutlar dönemin geleneksel konut tiplerini sergilemektedir (Şekil 9c). Sokağı oluşturan konutlar oturanların sosyo-ekonomik durumlarını yansıtan yapıdadır. Cumbalı, ahşap kaplamalı, kırma çatılı ve en fazla iki veya üç kattan oluşan bu konutlar özgün ve tipik eserler olduklarından günümüze kadar varlıklarını korumayı başarabilmişlerdir. Bölgede hem kent ticaretinde önemli yere sahip kapancıların yaşaması, hem de ilk vali Sırrı Paşa'nın konağının bulunması, bölgenin erişilebilirliği ve yaşanabilirliği yüksek bir bölge olduğunun kanitıdır.

80'li yıllardan sonra tarihi bölge çeperinde oluşan yakın çevre paralel dokudan oluşmaktadır. Bazı sokaklar, planlama kapsamının dışında, konut alanlarına erişim ihtiyacı doğrultusunda sonradan açılmış olup çıkmaz sokak niteliğindedir (Rasathane Çıkmazı).

Bölgenin batı kesiminde iklimsel verilerin ölçülmesi ve kayıt altına alınması için Rasathane (gözlem evi) bulunmaktadır (Rasathane Sokak).

Bölgede bulunan mekânlar inşa edildikleri dönemlerin mimari karakterini yansıtmakta ve toplumsal yapı hakkında önemli izler taşımaktadır. Tarihi bölge içerisinde ibadet, toplanma, yıkanma, alışveriş gibi birçok günlük ihtiyacın karşılandığı anlaşılmaktadır. Bölgenin birçok kamusal alanı özellikle döneminde önemli bir kentsel işaret niteliği taşımaktadır. Ancak günümüzde bu landmarkların bir kısmı yok olmuş ya da önemleri azalmıştır.

\section{Yerin topluma ilişkin anlamı}

1920 'lere ait veriler Osmanlı döneminin sosyal ve ticari yaşamı hakkında bilgiler vermektedir. Orhan Gazi'nin, Akçakoca Bey'in, Sırrı Paşa'nın, Hasan Elbeyoğlu'nun ve Hacı Hürrem'in sokaklara isimlerinin verilmesi ve günümüze kadar değişmeden gelmesi Osmanlı döneminin bu bölgenin belleğindeki önemini açıkça ortaya koymaktadır (Orhan Caddesi, Akçakoca Sokak, Sırrı Paşa Caddesi, Hasan Elbeyoğlu Sokak ve Hacı Hürrem Sokak). Orhan Gazi (Şekil 10a), Osmanlı İmparatorluğu'nun ikinci padişahıdır. Orhan Gazi, 1337 yılında önemli bir ticaret merkezi olan İzmit ve çevresini fethetmiştir. Akçakoca Bey (Şekil 10b)'de Osmanlı İmparatorluğunda önemli bir komutandır. Ertuğrul Gazi, Osman Gazi ve Orhan Gazi ile birlikte İzmit ve Sakarya bölgelerine baskınlar yapmış, ancak Kocaeli'nin fethinden önce 1328 yılında vefat etmiştir. Sırrı Paşa 1880'lerin Kocaeli valiliğini yapmıştır. Hasan Elbeyoğlu 1930'larda bölgenin muhtarıdır. Hacı Ayvaz, Hacı Hürrem ve Fehimoğlu bölgede yaşayan tanınmış, bilinen, önem verilen şahsiyetlerdir (Hacı 
Ayvaz Sokak, Hacı Hürrem Sokak ve Fehimoğlu Sokak). İnönü ve Saadettin Yalım gibi isimler ise Cumhuriyet döneminin de bölgenin belleğindeki yerini öne çıkarmaktadır (İnönü Caddesi, Saadettin Yalım Caddesi). İnönü (Şekil 10c), Türkiye Cumhuriyeti'nin ilk başbakanı ve ikinci cumhurbaşkanı olup, Cumhuriyet' imizin kuruluşunda önemli roller üstlenmiş bir devlet adamıdır. Saadettin Yalım (Şekil 10d) ise; Türkiye Büyük Millet Meclisi (TBMM) 10. ve 11. Dönem Kocaeli parlemento üyesidir. Bu durum, Kurtuluş Savaşı́nın ve Cumhuriyet liderlerinin toplumsal önemini göstermektedir. Dönemin bu önemli şahsiyetlerinin isimleri günümüze kadar değişmeden gelmiştir. Toplumsal bellekte Osmanlı ve Cumhuriyet dönemlerinin önemi büyüktür. Önemli kişilerin isimlerinin sokak ismi olarak kullanılması dönemin toplumsal yaşamındaki sınıf düzenlemesini ifade etmektedir. Ayrıca, mahalle muhtarının toplumsal yaşamdaki yeri de önemlidir. Bununla birlikte önemli bir tüccar olan Hacı Kirkor ismi 1920'lerde bölgede Ermenilerin yaşadığını göstermektedir (Hacı Kirkor Sokak). Böylece Akçakoca tarihi bölgesinde hem Müslüman hem de gayrimüslimlerin bir arada yaşamakta olduğu anlaşılmaktadır.
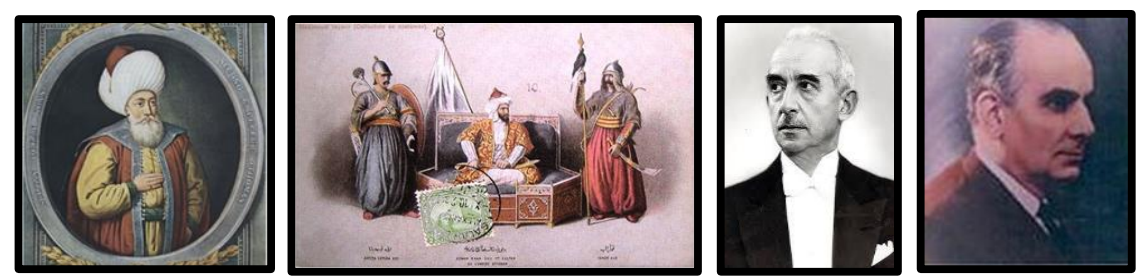

Şekil 10. Orhan Gazi (a) (“Orhan Gazi”,t.y.), Akçakoca Bey (b) (“Kocaeli'ye adını verdi: Türkmen Beyi Akçakoca", 2013), İnönü (c) (“İsmet İnönü", t.y.) ve Saadettin Yalım (d) ("İzmit Belediyesi”, t.y.)

Birçok sokağın bağlantı kurduğu pazar alanı, bölgenin bir toplanma ve ticari faaliyet yeridir (Yukarı Pazar'dan Aynalı Kavak'a Giden Yol, Yukarı Pazar'dan Kandilli Camii Şerifi'ne Giden Sokak, Hacı Ayvaz Camii Şerifi'nden Yukarı Pazara Giden Sokak, Bozoklu Meydanlığı'ndan Yukarı Pazar'a Giden Sokak). Çamaşırhane olarak kullanılan mekân, dönemin toplumunun çamaşır yıkama işlemini ortak bir mekânda gerçekleştirdiği göstermektedir. Çeşmeler ise ortak su alma noktasını ifade etmektedir. 1920'lerde tekkelerin varlığını ifade eden sokak ismi toplumsal yaşamda tarikatların varlığını da göstermektedir (Tekke Bahçesi Sokak). Dolayısıyla bireyler birçok işlevi bir arada gerçekleştirmektedir.

Dönemin toplumsal yaşamında ticaretin göstergelerinden olan bakkal, flrın, çakmakçı ve zeytinci gibi ticari işletmeler mahalle içinde yer almaktadır 
(Fırın Sokak, Zeytinci Sokak, Çakmakçı Sokak). Bölgede yaşayanlar evlerinden çok fazla uzaklaşmadan alışveriş ihtiyaçlarını karşılamışlardır. Kuzeyde bulunan bağlık alan ise, bağcılık ile uğraşan kişilerin burada yaşadığını göstermektedir (Bağçeşme Yolu). Ayrıca bölgenin batısındaki alanda bulunan tabakhanenin mahalle içinde yer aldığı ifade edilmektedir (Tabakhane Yolu). Bu durum da ticaret alanlarının çoğu zaman konut alanları arasında olduğunun göstergesidir. Sırrı Paşa'nın konağı hem konut hem ofis olarak kullanıldığından dönemin devlet işlerinin birlikte yürütüldüğünü göstermektedir. Kapancıların oturduğu sokak ise; Osmanlı dönemi ticaretinde kapancı mesleğinin varlığını, kapancıların önemli bir sosyal sınıf olduğunu ve kapancların çalıştığ1 Kapanönü'nün kent merkezinde önemli bir ticari odak olduğunu göstermektedir (Kapanca Sokak).

Sokak isimlerinde ulusal düzeyde bilinen askeri-politik nitelendirmelere, kentin milletvekili ve yöneticilerine, bölgede yaşayan yönetici, ticaretle uğraşan, toplumsal hayatta iz bırakan önemli kişilere ve mesleklere yer verilmesi, bölgenin toplumsal olarak çeşitliliğini de göstermektedir.

Akçakoca tarihi bölgesinin yere ait bileşenler olarak hem doğal, hem mekânsal, hem de toplumsal açlardan güçlü ve zengin bir yer olduğu anlaşılmaktadır.

\section{Sonuç}

Son yıllarda kentsel ortamlar küreselleşmenin yarattı̆̆ aynılaşma, tek tipleşme gibi unsurlarla yer olmayanların çoğaldığı bir yapı sergilemektedir. Bireyler kentsel ortamlar ile sürekli ilişki içerisinde olduklarından, karakter ve özgünlüğü ile akıllarda iz bırakan yer ile ilişki kuramadıklarında zamanla yaşanılan ortama ve kendi varlıklarına yabancılaşmaktadır. Bu nedenle yer olgusu; son yıllarda özellikle mekân ve toplum çalışmalarında giderek önem kazanmaktadır. Yer ile ilgili yapılacak araştırma ve çalışmaların birinci koşulu ise o yeri anlamaktır.

Bir yeri anlamak, o yerin doğal, mekânsal, toplumsal bileşenlerinin birbiriyle ilişkilerini kavramayı gerektirir. Yer isimleri, eşsiz olmalarından ve karakteristik dilsel öğeler içermelerinden dolayı ait oldukları bölgenin geleneklerini, tarihini, çeşitli kültürel konularını ve gelişiminin farklı evrelerini yansıtırlar. $\mathrm{Bu}$ nedenle yer isimleri yeri anlamak için önemli bir araştırma alanı oluşturmaktadır. Yerin kentsel ortamdaki en küçük kamusal ögesi olarak sokak ve sokak isimleri, gündelik hayatın içinde yer aldığından, sosyal hayatın oluşmasında, kültürel dokunun algılanmasında ve tarihin aktarımında önemli rollere sahiptir. Sokağı anlamak, o bölgeyi, kenti, ülkeyi anlamanın ilk adımıdır. 
Bu makale anlam analiz yöntemlerinden semiyolojik ve hermeneutik yöntemler aracilı̆̆yla sokak isimlerine gömülü olan yerin anlamına ilişkin doğal, mekânsal ve toplumsal göstergeler üreterek yorumlama yaklaşımı önermektedir. Öneri yaklaşım, yeri anlamak için bir yol haritası niteliği taşımaktadır.

$\mathrm{Bu}$ yol haritası aracilığıyla İzmit /Akçakoca tarihi bölgesinde yapılan çalışma, sokak isimlerinin geçmişten günümüze bir yerin anlamının işareti olduğunu, bilgi kartlarını oluşturarak ve analiz ederek yerin anlamı hakkında önemli bilgi ürettiğini göstermiştir.

İzmit /Akçakoca tarihi bölgesinde yeri anlamak için öncelikle her bir sokağın anlamından doğal, mekânsal, toplumsal başlıklarında göstergeler üretilmiştir. Buna göre bölgede sokak isimleri bilgi kartlarından üretilen yerin anlamına ilişkin 86 adet gösterge tespit edilmiştir. Yerin doğasına ilişkin anlamını oluşturan göstergeler; iklimsel, topoğrafik, botanik, ve jeolojik özellikleri barındırmaktadır. Bölge, iklimsel açıdan 1lıman, eğimli bir topoğrafyaya sahip, bitkisel çeşitlilik gösteren ve jeolojik açıdan zengin bir yapı sunmaktadır. Yerin mekana ilişkin anlamını oluşturan göstergeler; meydanlar, pazar alanları, camiler, ticaret alanları, konaklar ve çeşmelerdir. Gerek kamusal gerekse ekonomik hayatın gerçekleştiği bu mekanlar bölgenin yapısal anlamda gelişmiş olduğunu göstermiştir. Yerin topluma ilişkin anlamını oluşturan göstergeler ise; dönemin mesleklerine, iş alanlarına, yerel ve ulusal anlamda önemli kişilere işaret etmektedir. Sokak isimlerinde hem ulusal düzeyde hem de kent ve yerel düzeyde bilinen askeri-politik nitelendirmelere, kentin milletvekili ve yöneticilerine, bölgede yaşayan yönetici, ticaretle uğraşan, toplumsal hayatta iz bırakan önemli kişilere ve mesleklere yer verilmesi, bölgenin toplumsal olarak çeşitliliğini de göstermiştir. Böylece, İzmit/Akçakoca tarihi bölgesinin hem doğal, hem mekânsal, hem de toplumsal açlardan güçlü ve zengin bir yer olduğu anlaşılmıştır.

Yer'i sokak isimleri aracılığıyla anlamak için önerilen yol haritası, amaçlarına göre farklı disiplinler tarafından değerlendirilebilir ve / veya geliştirilebilir. Mimarlar ve kent plancıları koruma, tasarım ve planlama çalışmalarında, ekonomistler yatırım ve turizm geliştirmelerinde, sosyologlar toplumsal araştırmalarında ve peyzaj mimarları yeşil alan çalışmalarında yerin anlamının araştırıcısı olarak sokak isimlerini analiz edebilirler ve bilgi üretebilirler.

Sonuç olarak bu çalışma, sokak isimlerinin yerin anlamının araştırıcısı olduğunu ve bu anlama erişmede sokak isimlerinin tanımlanmasının, korunmasının ve belgelenmesinin gerekliliğini ortaya koymuştur. 


\title{
Extended Abstract
}

\section{Street Names behind investigating the meaning of "Place": İzmit/Akçakoca Historical Core Case}

\author{
Zeynep Gamze Mert \\ ORCID: 0000-0003-1896-4652
}

\author{
Filiz Ertürk \\ ORCID: 0000-0003-4105-3929
}

In recent years, urban environments have formed into the elements such as the sameness and uniformization created by globalization. The residents are in constant contact with urban environments. When they cannot establish a relationship with the place, it leaves a mark in mind with its character and originality, and they become alienated from the environment they live in and their own existence. Therefore, the phe-nomenon of place is becoming increasingly important especially in spa-ce and community studies. The concept of place has been studied by many researchers from different perspectives. Some have approached the concept as a social and cultural structure, some as a location, some in terms of identifying features, and some as a field of experience. The first condition of research and studies about the place is to understand that place. Understanding a place requires understanding the interrela-tionships of the natural, spatial and social components of that place. Place names constitute an important research area for understanding the place, as they reflect the traditions, history, various cultural issues and different stages of its development due to its relation with the language. Understanding the street is the first step to understand a region, city and country. The street and street names have an impor-tant role in the formation of social life, in the perception of cultural texture and in the transfer of history due to their inclusion in daily life. Studies on street names in the literature show that dominant ideologies reflect the political, social and historical contexts of their period to street names. In addition, as an indicator of identity, the studies em-phasized that street

naming is a tool in identity construction. In the literature review, it has been found out that there is no study investigating the meaning of the place through the relations of the natural, spatial and social compo-nents of the place embedded in the street names. This study aims to define the street names as the researcher of the meaning of the place with a proposed roadmap. 
The roadmap consists of 3 stages. The first stage is to acquire indi-cators of street names in a defined area, the second stage is to design and create the "Street Name / Names Information Card" in which these indicators are recorded for each street, and the third stage is the stage of understanding the whole place through the indicators produced from street names. The method used in determining the indicators of the street or streets within the defined area is semiotics. Street names play an important role as indicative and indicated in the formation of social life, in the perception of cultural texture and in the transfer of history. In this study, in order to generate information within the fra-mework of semiology, which is one of the meaning-seeking methods, street names are approached with $5 \mathrm{~W} 1 \mathrm{H}$ questions that allow detailed thinking. "What?" question's answer is the street name, "Where?" question's answer is the location of the street, "When?" question's answer is the period of street naming, "Who?" question's answer is the authority of street naming, "How?" question's answer is the tools of application, "Why?" question's answer is the meaning of street. The indicators acquired through $5 \mathrm{~W} 1 \mathrm{H}$, are gathered and recorded on the"Street Name Card".

The method used in the interpretation phase is hermeneutic. The indicators are organized according to the features of the place which are natural, spatial and social. Then, the meaning of the place is revea-led through interpreting the indicators.

The roadmap proposed in this study is illustrated regarding street names of Akçakoca historical core region in İzmit/Kocaeli/Turkey. Akçakoca region is one of the first settlements found after the conquest of the city by the Ottoman Empire. Akçakoca historical district consists of 20 streets today. Together with the oldest 1925 Ottoman Plans and 2020 plans of the study area were examined, it was understood that the physical pattern did not change significantly. However, in addition to these maps, when other maps and parliamentary decisions were examined, it was understood that the street names changed periodi-cally. Based on these changes, four time sections $(1925,1965,1995,2020)$ have been identified. This study determines 48 street names. In order to understand the place, 4 natural (climatic, topographic, botani-cal and geological); 5 spatial (residential areas, public spaces, commer-cial areas, private spaces and urban elements); 4 social (local name, national name, job, profession) and 1 adjective indicators were produ-ced. Accordingly, 86 indicators were identified regarding the meaning of the place. Thus, it has been understood that the Izmit / Akçakoca historical core region is a powerful and rich place in terms of natural, spatial and social aspects. 
Through the roadmap, the study conducted in the historical region of Izmit / Akçakoca has shown that street names are signs of the mea-ning of a place from past to present, and that they generate important information about the meaning of the place by creating and analyzing information cards. As a result, this study revealed that street names are the researchers of the meaning of the place and should be defined, protected, documented and conveyed.

\section{Kaynakça/References}

Akerson, F. E. (2016). Göstergebilime giriş. İstanbul: Bilge Kültür Sanat Yayınevi.

Aliağaoğlu, A. ve Uzun, A. (2011). Şehirsel toponimi (hodonimi): Türkiye için bir tipoloji denemesi. Coğrafi Bilimler Dergisi, 9 (2), 123-133.

Assmann, J. (2015). Kültürel bellek, eski yüksek kültürlerde yazı hatırlama ve politik kimlik (2. Bs.). (A. Tekin, Çev.). İstanbul: Ayrıntı Yayınevi. (Orijinal eserin yayın tarihi 1997).

Augé, M. (2016). Yok-yerler (2. Bs.). (T. Ilgaz, (Çev.). İstanbul: Daimon Yayınları. (Orijinal eserin yayın tarihi 1992).

Azaryahu, M. ve Kook, R. (2002). Mapping the nation: Street names and Arab-Palestinian identity: Three case studies. Nations and Nationalism, 8 (2),195-213.

Barthes, R. (1993). Göstergebilimsel serüven (2.Bs.).(M. Rifat veS. Rifat(Çev.). İstanbul: Yap1 Kredi Yayınları.

Bodnar, E. (2009). I have often walked down this street before... but what was it called? Changes to street names in Budapest from the end of Turkish rule to the present. Past Imperfect, 15, 115-153.

Bollnow, O. F. (1995). İfade ve anlama. D. Özlem (Der.). Hermeneutik (Yorumbilgisi) Üzerine Yazılar içinde (s.83-122). Ankara: Ark Yayınevi.

Bucher, S., Matlovi, R., Lukáčová, A., Harizal, B., Matlovičová, K., Kolesárová, J., . . Michalko., M. (2013). The perception of identity through urban toponyms in the regional cities of Slovakia. Anthropological Notebooks. 19 (3), 23-40.

Costa, F. S. (2012). Street names, politics of memory and social debate in Republican Barcelona (1931-1936): A theoretical reflection and case study. Catalan Journal of Communication \& Cultural Studies, 4 (1), 3-19.

Dilthey, W. (1999).Hermeneutik ve tin bilimleri.(D. Özlem, Çev.). İstanbul:Paradigma Yayınları. Ertürk, F. (2019). Fotoğraf Arşivi. Akçakoca Mahallesi. İzmit.

Gadamer, H. G. (1995) Hermeneutik. D. Özlem (Der.). Hermeneutik (Yorumbilgisi) Üzerine Yazlar içinde (s.9-28). Ankara: Ark Yayınevi.

Gadamer, H. G. (2008). Hakikat ve yöntem. (H. Arslan ve İ. Yavuzcan, Çev.). İstanbul: Paradigma Yayınları. (Orijinal eserin yayın tarihi 1960).

Gnatiuk, O. (2018). The renaming of streets in post-revolutionary Ukraine: Regional strategies to construct a new national identity. AUC Geographica. 53(2), 119-136.

Grondin J. (2017). Hermeneutik. Cogito, 89, 7-41.

Halihazır Harita. (2020). İzmit Belediyesi İmar ve Şehircilik Müdürlüğü arşivi. 
Heidegger, M. (2004). Varlık ve zaman. (A. Yardımlı, Çev.). İstanbul: İdea Yayınevi. (Orijinal eserin yayın tarihi 1926).

İsmet İnönü. (t.y.). Wikipedia: 11 27, 2020 tarihinde https://tr.wikipedia.org/wiki/\%C4\%B0smet_\%C4\%B0n\%C3\%B6n\%C3\%BC adresinden alındı

İzmit Belediyesi. (t.y.). İmar ve Şehircilik Müdürlüğü Arşivi.

İzmit Belediyesi. (t.y.). Eski başkanlarımı. 11 27, 2020 tarihinde http://www.izmit.bel.tr/kurumsal/eski-baskanlarimiz_0145/adresinden alındı

Jacobs, J. (2017). Büyük Amerikan şehirlerinin ölümü ve yaşamı (3. Bs.). (B. Doğan, Çev.). İstanbul: Metis Yayıncllk. (Orijinal eserin yayın tarihi 1961).

Kocaeli Rehber. (t.y.). Kocaeli Büyükşehir Belediyesi. 11 27, 2020 tarihinde https://rehber.kocaeli.bel.tr/@40.7646503,29.9219248,6z adresinden alındı

Kocaeli'ye adını verdi: Türkmen Beyi Akçakoca. (2013, 04 20). Akçakoca Tv. 11 27, 2020 tarihinde http://www.akcakocatv.com/haber-detay.asp?id=3100 adresinden alındı

Krier, R. (1991). Urban space. (5. bs.). Hong Kong: Academy Editions.

Light, D. (2004). Street names in Bucharest, 1990-1997: Exploring the modern historical geographies of post-socialist change. Journal of Historical Geography. 30, 154-172.

Norberg-Schulz, C. (1980). Genius loci towards a phenomenology of architecture. New York: Rizzoli International Publication.

Norberg-Schulz, C. (1971). Genius loci, existence space and architecture. London: Studio Vista

Wikipedia. (t.y.). Orhan Gazi. 11 27, 2020 tarihinde https://tr.wikipedia.org/wiki/Orhan_Gazi adresinden alındı

Rapoport, A. (1987). Pedestrian street use: Culture \& perception public street for public use. New York: Van Nostrand Reinhold Company.

Relph, E. (1976). Place and placelessness, London: Pion Limited.

Rusu, M.S. (2019). Shifting urban namescapes: Street name politics and toponymic change in a Romanian(ised) city. Journal of Historical Geography. 65, 48-58.

Særheim, I. (2009). Street names and identity: Official naming in a European capital of culture. W. Ahrens, S. Embleton ve André Lapierre (Der. ), Proceedings of the 23rd International Congress of Onomastic Sciences içinde (s. 860-865). Toronto, York University.

Shoval, N. (2013). Street-naming, tourism development and cultural conflict: The case of the old city of Acre/Akko/Akka. Transactions of the Institute of British Geographers. 38, 612-626.

Stiperski, Z., Lorber L., Heršak E., Ptaček P., Górka Z., Koloś A., . . Hruška, A. (2011). Identity through urban nomenclature: Eight central European cities. Geografisk Tidsskrift-Danish Journal of Geography. 111 (2),181-194.

5393 sayıl belediye kanunu (2005). Resmi Gazete (Sayı: 25874)..Ankara,

5216 sayılı büyükşehir belediyesi kanunu (2004). Resmi Gazete (Sayı: 25531). Ankara.

Vasile, I.A. ve Bordusanu S. (2014). A cultural perspective: Suggestion for a documentary film. The toponymic heritage of Bucharest streets bearing Jewish names. Cinematographic Art E Documentation. 09 (13), 43-51. 